\title{
Effect of smoking on autonomic reflexes
}

\author{
K. Singh, S. Sood
}

\begin{abstract}
Abstrak
Pengaruh merokok sigaret terhadap refleks otonom diteliti para 25 perokok pria dibandingkan dengan 25 bukan perokok yang komparabel. Tidak didapat perbedaan bermakna dalam frekuensi denyut jantung, tekanan darah dan variabel lain pada kedua kelompok sebelum merokok. Namun pada kelompok perokok, sesudah merokok, denyut jantung basal, tekanan darah basal (<0,001), tekanan diastolik $(p<0,05)$ dengan perubahan posisi, tekanan sistolik $9 p<0,01)$ pada cold pressure test semuanya meningkat. Rasio ekspirasi : inspirasi $(p<0,01)$ dan $S: L(p<0,01)$ menurun. Observasi ini menunjukkan peningkatan akut pada lintas simpatik dengan pengaruh pada aktivitas vagal. (Med J Indones 2001; 10: 95-7)
\end{abstract}

\begin{abstract}
Effect of cigarette smoking on autonomic reflexes was tested in 25 male smokers and compared with 25 age, sex matched non smokers. There was insignificant difference between heart rate $(H R)$, blood pressure $(B P)$ and other variables between non smokers and smokers (before smoking). But in smokers after cigarette smoking, the basal HR, basal BP $(<0.001)$, diastolic BP (p $<0.05)$ with change of posture (lying to standing), systolic $B P(p<0.01)$ on cold pressure test were all increased, while expiration: inspiration (E:I) ratio $(p<0.01)$ and $S: L$ ratio $(p<0.05)$ were reduced. These observations indicate acute rise in sympathetic traffic with some effect on vagal activity. (Med J Indones 2001; 10: 95-7)
\end{abstract}

Keywords: smoking, autonomic reflexes, sympathetic, vagus

Duration and number of cigarettes smoked per day are directly proportional to cardiac morbidity and mortality. In addition to 4000 substances, nicotine and carbon monoxide components of cigarette smoke are supposed to affect cardiovascular system, ${ }^{\text {' increase }}$ arterial pressure and heart rate acutely. ${ }^{2}$ Effects of smoking on sympathetic activity are not well understood. Smoking or nicotine infusion may increase, decrease or may not have any change in epinephrine levels. ${ }^{3}$ Nicotine has been found to decrease $^{4}$ or to have no effect ${ }^{5}$ on directly recorded muscle sympathetic nerve activity. We conducted this study to find out acute autonomous consequences of smoking in asymptomatic smokers and compared with non smokers.

Department of Physiology, Pt. B.D. Sharma Postgraduate Institute of Medical Sciences (PGIMS), Rohtak-124001, Haryana, India
The present study was carried out in 25 male smokers and compared with 25 age, sex, height and weight matched nonsmokers. A detailed history of smoking was gathered from each smoker with special reference to duration of smoking, number of bidi/cigarette smoked/day and the age of starting smoking. All the subjects were examined clinically to exclude any underlying cardiac disease. Subjects with haemoglobin level less than $10 \mathrm{~g} \%$ were excluded from the study. Subjects were asked to abstain from smoking for 2 hours before the tests. All the tests were performed in morning. Smoking of one cigarette (Red and white, Marcitch, nonfilter) was followed by smoking of another cigarette. Both the cigarettes were finished within 10 minutes (range 5.2 to $7.5 \mathrm{~min}$, average time 5.35 minute). Each cigarette was smoked to a butt length of $4.2 \mathrm{~cm}$ (total length $6.7 \mathrm{~cm}$ ). Data were collected in nonsmokers, and in smokers before and after smoking.

Autonomic reflexes: Following noninvasive tests were carried out:

(1) Deep breathing test: First subjects were taught and shown deep breathing test. They were instructed 
to take 6 deep breaths each of $10 \mathrm{sec}$. The E:I ratio then was calculated as:

$$
E: I \text { ratio }=\frac{\text { Maximum } R-R \text { interval during expiration }}{\text { Minimum R-R interval during inspiration }}
$$

(2) Effect of posture: Effect of change of posture from lying to standing was recorded on heart rate (HR) and blood pressure (BP).

(3) $S: L$ ratio: It is the ratio of longest $R-R$ interval during five beats before lying down to the shortest $\mathrm{R}-\mathrm{R}$ interval during the 10 beats after lying down (standing to lying ratio).

(4) Valsalva manoeuvre (VM): All the subjects were shown the procedure of VM. Then they were asked to expire forcefully in a tube against closed glottis to raise and maintain pressure of $40 \mathrm{mmHg}$ for $15 \mathrm{sec}$. Valsalva ratio and blood pressure were recorded during strain (Phase II) and after release of strain (Phase IV).

$$
\begin{aligned}
& \text { Longest R-R interval after manoeuvre } \\
& \text { (phase IV) } \\
& \begin{array}{l}
\text { Valsalva }= \\
\text { Ratio }
\end{array} \text { Shortest R-R interval during manoeuvre } \\
& \text { (phase II) }
\end{aligned}
$$

(5) Cold pressure test (CPI): Subject was asked to immerse his left hand in cold water $\left(5-8^{\circ} \mathrm{C}\right)$ upto wrist for $1 \mathrm{~min}$. Heart rate (HR) and blood pressure (BP) were recorded just after withdrawl of hand from cold water. ${ }^{6}$

Heart rate recording was taken on physiograph continuously at speed of $25 \mathrm{~mm} / \mathrm{sec}$. Blood pressure was recorded by sphygmomanometer. Data were analysed statistically by using paired and unpaired ' $\mathrm{t}$ ' test.

\section{RESULTS}

Subjects we studied indicated that they smoked 7 to 30 (mean 14.5) beedis/cigarettes daily for 2 to 15 years (mean 10.6 years) (Table 1). There was insignificant difference between HR, BP and other variables between nonsmokers and in smokers before smoking (Table 2). In smokers, on cigarette smoking (i) the basal HR and BP were increased significantly ( $p<0.001$ ), (ii) with change of posture from lying to standing the diastolic BP ( $\mathrm{p}<0.05)$ and on CPT the systolic BP (p<0.01) were elevated, (iii) while E:I ratio $(p<0.01)$ and $S: L$ ratio $(p<0.05)$ were reduced (Table 3). Effect of VM on HR and BP is given in Table 1 and 3.

Table 1. Physical characteristics of subjects

\begin{tabular}{lcc}
\hline Characteristics & $\begin{array}{c}\text { Nonsmokers } \\
(\mathrm{n}=25)\end{array}$ & $\begin{array}{c}\text { Smokers } \\
(\mathrm{n}=25)\end{array}$ \\
\hline Age (years) & $31.6 \pm 9.17$ & $34 \pm 7.33$ \\
Quetelet Index & $2.29 \pm 0.34$ & $2.22 \pm 0.37$ \\
No. of beedi/cigarette & - & $14.58 \pm 9.20$ \\
Duration of smoking & - & $10.66 \pm 5.92$ \\
Age at which smoking & - & $18.41 \pm 2.21$ \\
was started & & \\
\hline
\end{tabular}

Table 2. Comparison of autonomic function tests between nonsmokers and smokers (before smoking)

\begin{tabular}{lccc}
\hline Parameters & Non-smokers & $\begin{array}{c}\text { Smokers } \\
\text { (before } \\
\text { smoking) }\end{array}$ & p value \\
\hline Heart rate (beats/min) & $72.42 \pm 15.17$ & $66.17 \pm 19.77$ & NS \\
Blood pressure (BP) & & & \\
(mmHg) & $124.93 \pm 14.94$ & $120.0 \pm 11.0$ & NS \\
$\quad$ Systolic & $76.93 \pm 12.84$ & $80.86 \pm 12.77$ & NS \\
$\quad$ Diastolic & $1.30 \pm 0.18$ & $1.30 \pm 0.12$ & NS \\
E:I ratio & $97.59 \pm 25.04$ & $102.59 \pm 13.37$ & NS \\
Effect of posture: & $125.6 \pm 14.48$ & $127.06 \pm 12.21$ & NS \\
Heart rate & $89.33 \pm 18.66$ & $89.73 \pm 9.92$ & NS \\
Systolic BP (mmHg) & $0.82 \pm 0.07$ & $0.85 \pm 0.10$ & NS \\
Diastolic BP (mmHg) & $1.55 \pm 0.32$ & $1.49 \pm 1.29$ & NS \\
S:L ratio & & & \\
Valsalva ratio & & & \\
Pulse pressure during & $32.09 \pm 3.05$ & $38.0 \pm 1.05 *$ & $<0.001$ \\
VM: & $44.86 \pm 1.23$ & $45.6 \pm 5.75$ & NS \\
Phase II & & & \\
Phase IV & $85.25 \pm 16.12$ & $82.64 \pm 8.01$ & NS \\
Cold pressure test & $139.06 \pm 15.24$ & $134.93 \pm 13.65$ & NS \\
Heart rate & $92.8 \pm 17.48$ & $98.93 \pm 13.48$ & NS \\
Systolic BP & & & \\
Diastolic BP & & & \\
\hline
\end{tabular}

* $<0.001$ Highly significant

$\mathrm{VM}=$ Valsalva manouvre

\section{DISCUSSION}

Most of the cardiovascular effects of smoking are thought to be mediated by sympathetic stimulation. In the present study a battery of autonomic provocative manouvres were performed to find effect of smoking, while most other workers have used only few of them. Basal HR and BP were almost similar between 
nonsmokers and smokers before smoking as has been reported earlier ${ }^{7-8}$ Increase in HR and BP in smokers after smoking as seen in this study, is consistent with other reports. ${ }^{8-10}$ This increase may due to elevated sympathetic activity. Smoking speeds up HR in part by reducing vagal restraints. ${ }^{10}$ This fact is supported by the finding that $E: I$ ratio and $S: L$ ratio are reduced in this study. Hayano and coworkers ${ }^{11}$ also showed that R-R interval spectral power at the respiratory frequency is reduced by smoking.

After smoking in Phase II of valsalva manouvre pulse pressure is increased sharply indicating the increased sympathetic response. In phase IV sympathetic activity is silenced causing reduced pulse pressure as reported by other workers. ${ }^{10}$

On CPT, rise in systolic blood pressure is more compared to diastolic after smoking showing an increased sympathetic traffic to the cutaneous vascular bed $^{12}$ and provokes skin vaso constriction. ${ }^{13}$

Conclusion: From this study, it is clear that responses to the same stimuli are similar in smokers and nonsmokers including basal heart rate and blood pressure. But smoking acutely increases sympathetic outflow with some restrain on vagal activity which needs further exploration.

\section{REFERENCES}

1. Holbrook JH. Nicotine addiction. In: Isselbacher $\mathrm{KJ}$, Braunwald E, Wilson JD, Martin JB, Fauci AS, Karper DL editors. Harrison's Principles of Internal Medicine, $13^{\text {th }}$ ed, vol 2, New York, McGraw-Hill Inc. 1994:2433-7.
2. Lakier JB. Smoking and cardiovascular disease. Am J Med 1992; 93:1A-8S-12S.

3. Cinciripini PM, Benedict CE, Van Vunakis H, Mace R, Lapitsky L, Kitchens K, et al. The effects of smoking on the mood, cardiovascular and adrenergic reactivity of heavy and light smokers in a non stressfull environment. Biol Psychol 1989; 29:273-89.

4. Grassi G, Seravalle G, Calhoun DA, Bolla GB, Zanchetti A, Mancia G. Alteration in sympathetic nerve traffic during cigarette smoking in man: a preliminary report. J Hypertens 1991; 9 (Suppl 6): S52-53.

5. Mosqueda-Garcia R, Bioggioni I, Haile V, Robertson R, Robertson D. Effects of nicotine infusion on sympathetic nerve traffic and baroreflex response in man. Clin Res 1990; 38:259A (Abstract).

6. Mishra N and Mahajan KK. Cardiovascular response to orthostatic stress following cold challenge. Bio Med Res 1995; 61(1):103-7.

7. Gofin R, Kark JD, Friedlander Y. Cigarette smoking, blood pressure and pulse rate in the Jerusalem Lipid Research. Clinic Prevalence Study. Isr J Med Sci 1982; 18:1217.

8. Green MS, Jucha E, Luz Y. Blood pressure in smokers and nonsmokers: Epidemiologic findings. Am Heart $\mathbf{J}$ 1986; 111 (5):932-40.

9. Benowitz NL, Kuyt F, Jacob P. Influence of nicotine on cardiovascular and hormonal effects of smoking.

10. Niedermaier N, Smith ML, Beightol LA, Grojec ZZ, Goldstein DS, Eckberg DL. Influence of cigarette smoking on human autonomic function. Circulation $1993 ; 88: 562-71$.

11. Hayono J, Yamada M, Sakakibara Y, Fujinami T, Yokoyama K, Watanabe $\mathrm{Y}$, et al. Short and long term effects of cigarette smoking on heart rate variability. Am J Cardiol 1990; 65:84-8.

12. Delius W, Hogbarth KE, Hongell A, Wallin BG. Manoeuvers affecting sympathetic outflow in human skin nerves. Acta Physiol Scand 1972; 84:177-86.

13. Benowitz NL, Jacob P, Jones RT, Rosenberg J. Interindividual variability in the metabolism and cardiovascular effects of nicotine in man. $\mathrm{J}$ Pharmacol Exp Ther 1982; 221:368-72. 